\title{
ICOS wt Allele
}

National Cancer Institute

\section{Source}

National Cancer Institute. ICOS wt Allele. NCI Thesaurus. Code C94802.

Human ICOS wild-type allele is located in the vicinity of $2 \mathrm{q} 33$ and is approximately $25 \mathrm{~kb}$ in length. This allele, which encodes inducible T-cell costimulator protein, plays a role in the modulation of T-cell mediated immunity. Mutation of the gene is associated with common variable immunodeficiency type 1. 